\title{
農村景観についての多様な認識
}

\author{
一三重県伊賀市調查から一
}

The Various Recognition about the Rural Landscape:

From Investigation in Iga-City, Mie Pref.

\section{岩田 俊二*}

Shunji IwATA

\section{I はじめに}

景観法は農村地域をも対象にしているが，農村地域の 景観について何を対象に如何に計画するかについては, 近江八幡市丸山地区の計画事例があるものの不明確であ る。農村景観の多様性や由来に根ざした農村景観の賛美 については幾多の資料があるものの，景観計画の参考に なるような基礎的な研究成果は少ない。伊賀市でも伊賀 上野のお城周辺の城下町景観については早くから景観条 例を制定し，施策を講じてきたが農村地域については全
く手つかずのままである。そこで, 伊賀市農村地域の景 観計画の基礎的資料とすべく, 伊賀市農村の 3 地区を対 象に農村地域の景観構成要素の分析, 農村景観について の農村居住者の認識及び都市住民として三重短期大学学 生の認識をアンケート調査及び農村景観の形成基準の検 討を行った。この論考では農村地域の景観構成要素分析 と景観認識に焦点をあてて，いわば「ふるさと景観」を 農村地域の人は如何に認識しているか, その地域に無関 係な都市住民が期待する農村景観とは何かについて述べ てみたい。

表 1 景観アンケートにおいて「地区の特徴を示している（地元住民向け）」及び「農村のイメージにあう（三重短大生向け）」の回答率が 全設問全選択肢の平均以上の設問一比自岐地区一

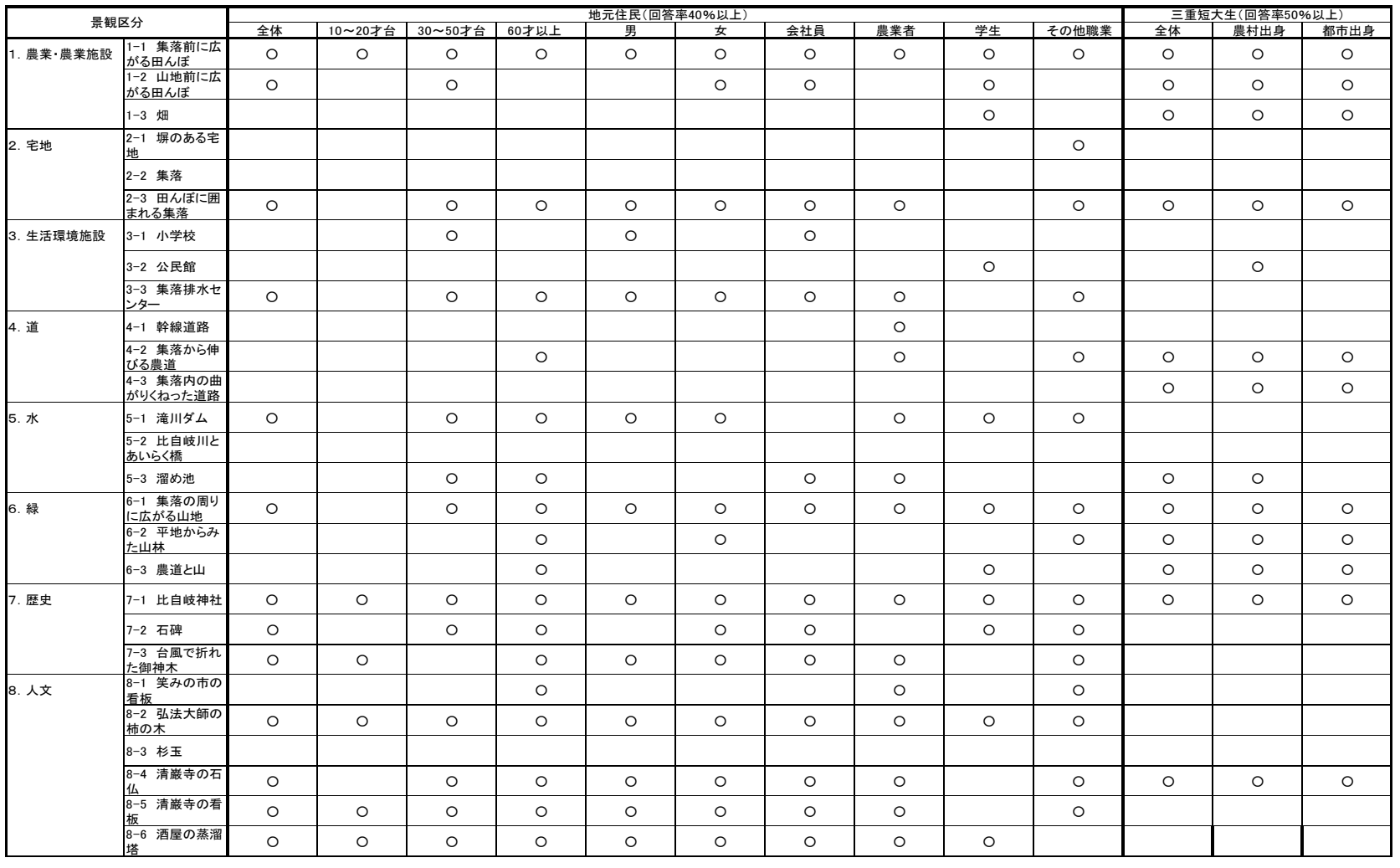

*津市立三重短期大学 Tsu City College

Key Words：1）農村景観，2）景観計画，3）景観認識 
1 農地・農業施設

1-1 集落前に広がる田んぼ

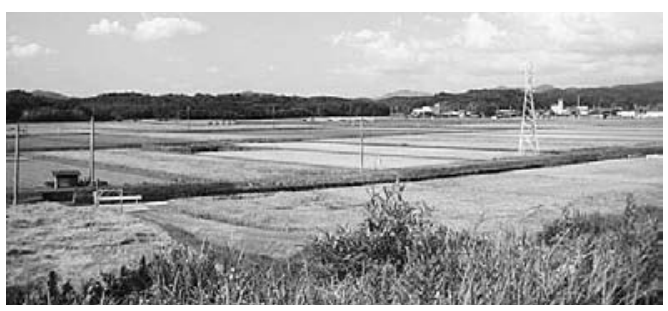

2 宅地

2-1 塀のある宅地

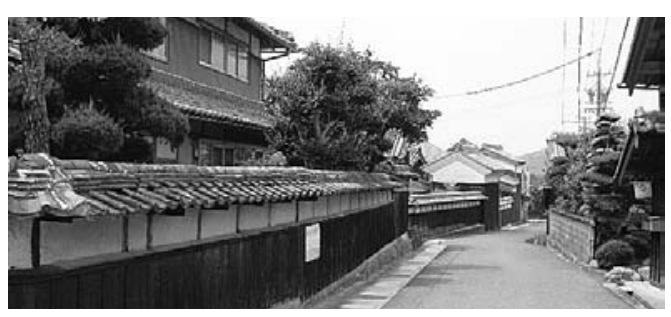

2-3 田んぼに囲まれる集落

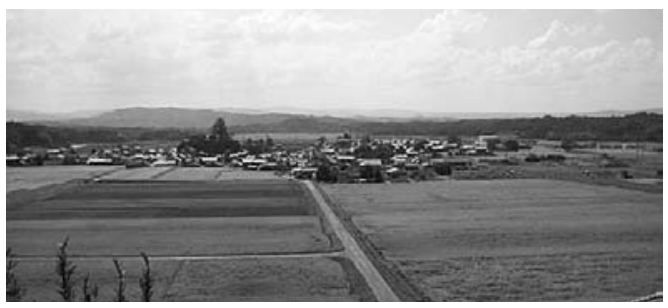

3 生活環境施設

3-3 集落排水センター

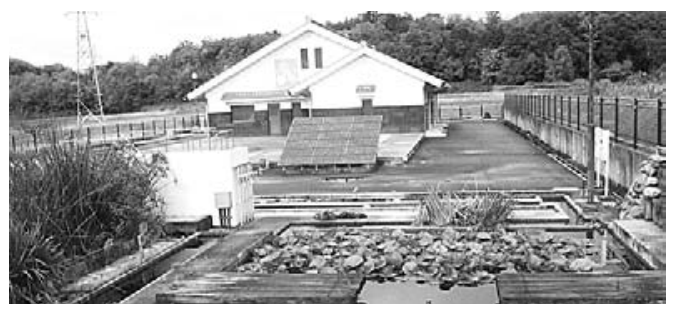

4. 道

4-1 幹線道路

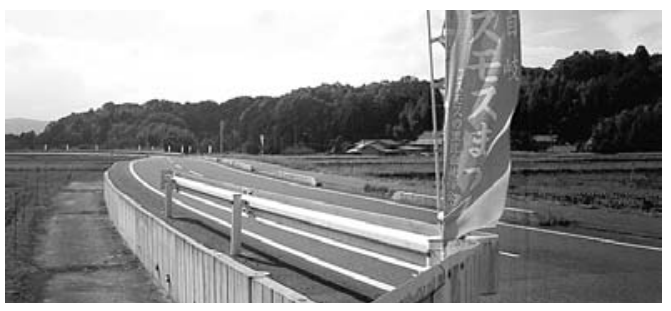

4-2 集落から伸びる農道

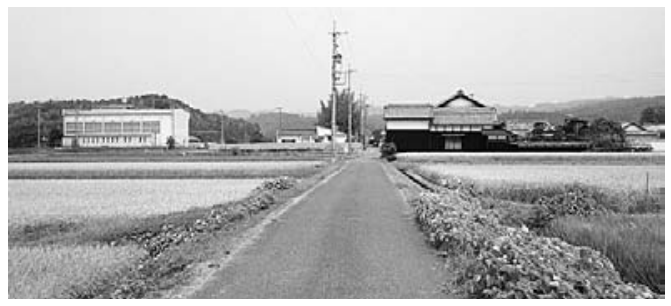

$0 \% \quad 20 \% \quad 40 \% \quad 60 \%$

地区の特徽を示している 地区の特徽を少儿示。

どちらとも言えない 地区の特徴をあまり示. $22 \%$ 地区の特徽を示してい... $2 \%$ 無回答 日2\%

\begin{tabular}{|l|l|l|}
\hline \hline $20 \%$ & \\
\hline 2 & $21 \%$ & \\
\hline $2 \%$ & \\
$2 \%$ & \\
$2 \%$ & & \\
\hline $2 \%$ &
\end{tabular}

$\begin{array}{lllll}0 \% & 10 \% & 20 \% & 30 \% & 40 \%\end{array}$

地区の特徴を示している 地区の特徽を少し示して。 どちらとも言えない 地区の特徽をあまり示 地区の特徽を示していない 無回答 18

\section{$0 \% \quad 10 \% 20 \% 30 \% \quad 40 \% 50 \%$}

地区の特徽を示している 地区の特徽を少儿示

どちらとも言えない 地区の特徽をあまり示口 19 地区の特徵を示してい... $4 \%$ 無回答

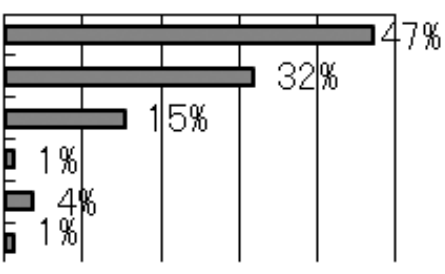

$0 \% 10 \% 20 \% 30 \% 40 \% 50 \% 60 \%$

地区の特徴を示している 地区の特徴を少し示している どちらとも言えない 地区の特徽をあまり示して。 地区の特徵を示していない 無回答

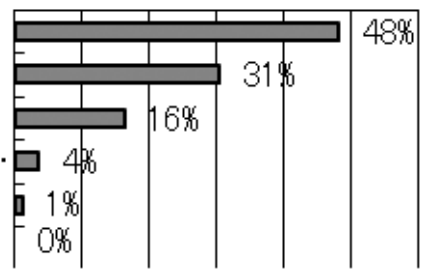

$0 \% \quad 10 \% \quad 20 \% \quad 30 \% \quad 40 \%$

地区の特徽を示している 地区の特徽を少儿示 どちらとも言えない 地区の特徽をあまり示 地区の特徽奆示してい. 無回管

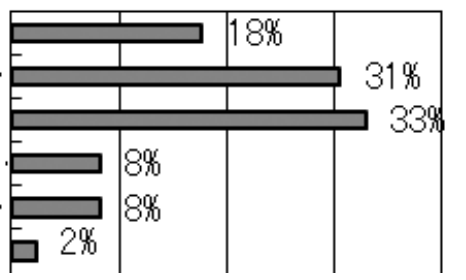

$0 \% \quad 10 \% \quad 20 \% \quad 30 \% \quad 40 \% \quad 50 \%$

地区の特徽を示している 地区の特徴を少儿示している

どちらとも言えない 地区の特徵をあまり示しで.占 $2 \%$ 地区の特徽を示していない百 $2 \%$ 無回答 $51 \%$ 


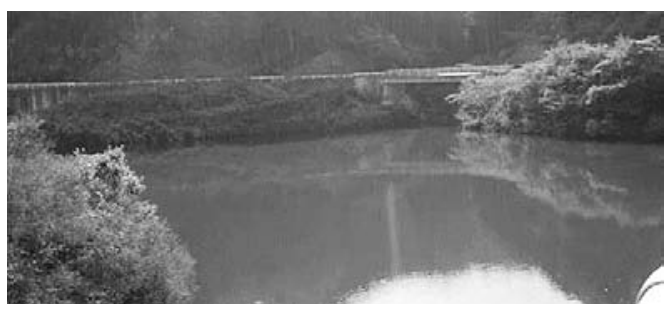

6 緑

6-1 集落の周りに広がる山地

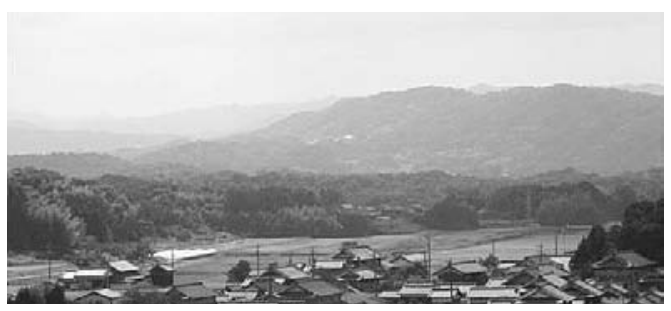

7 歴史

\section{$7-1$ 比自岐神社}

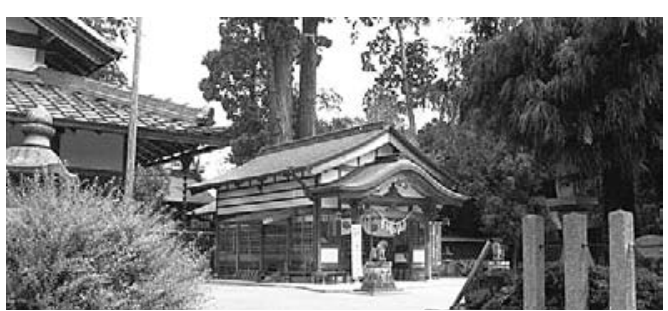

8 人文

8-2 柿の木

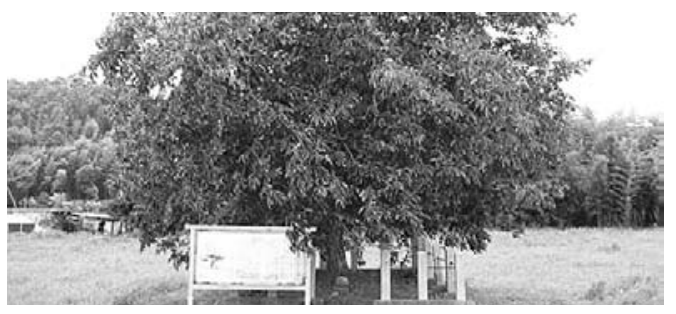

$0 \% \quad 10 \% \quad 20 \% \quad 30 \% \quad 40 \% \quad 50 \%$

地区の特徵を示している 地区の特徵を少儿示している どちらとも言えない 地区の特徴をあまり示してい 地区の特徵を示していない 無回答

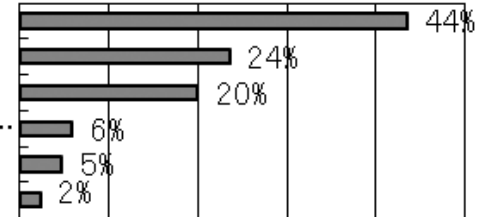

o\% 10\% 20\% 30\% 40\% 50\% $60 \%$

地区の特徵を示している 地区の特徵を少儿示している どちらとも言えない 地区の特徵をあまり示して・.”19 地区の特徵を示していない 19 無回答 7 O\%

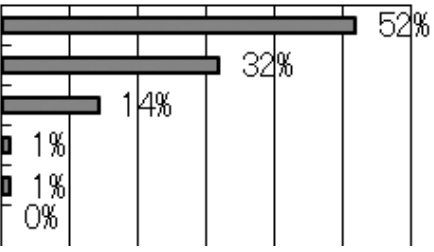

$0 \% 10 \% 20 \% 30 \% 40 \% 50 \% 60 \% 70 \%$

地区の特徴を示している 地区の特徽を少儿示している どちらとも言えない 地区の特徽をあまり示してい. 地区の特徽を示していない 無回答

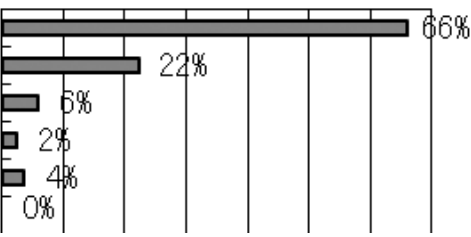

o\% 10\% 20\% 30\% 40\% 50\% 60\% 70\%

地区の特徵を示している 地区の特徵老少儿示ている どちらとも言えない 地区の特徽をあまり示してい、 地区の特徽を示していない

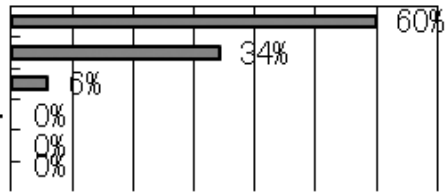

図 1 比自岐地区景観アンケート（全員）結果の抜粋

\section{II 研究方法}

調査対象地域は伊賀市景観条例等の調查研究をしたこ とがある伊賀市を選択し，その農村地域とした。対象の 農村集落は(1)種生地区一木津川の川上ダム予定地の上流 にある山間集落, (2)比自岐地区-盆地状の平坦地集落で 稲作を中心に集落営農が盛ん, (3)古山地区-名張上野街 道沿いの山裙集落である。

\section{1 景観構成要素の分析}

ア．景観構成要素の大分類は次のように設定し，この
大分類に基づき現地で写真撮影を行い, 景観構成要素図 を起こし景観構成要素を分析した。(1)農地・農業施設, (2)宅地, (3)生活環境施設, (4)道, (5)水·自然, (6)緑, (7) 歴史，8人文。イ．景観シーンを(1)遠景（大景観）(2)中 景 (中景観) (3)近景 (小景観)に 3 分類し分析した。ウ. シーンを前景, 主景, 背景に分解し景観構成要素を把握 した。

\section{2 地区別の景観についての住民アンケート}

景観構成要素の分析結果及び地区の区長さん等代表者 との協議に基づき地区の特徵的で代表的な景観を設定し （種生地区 29 シーン, 比自岐地区 27 シーン, 古山地区 
18 シーン), 15 歳以上の住民の意向をアンケート調査し た。種生地区 73 名, 比自岐地区 85 名, 古山地区 95 名。 分析単位は(1)全体, (2)男女, (3)年齢, (4)職業。

\section{3 地区別の景観について三重短大学生アンケート}

同じ景観について都市在住者の意向を探るため, 三重 短期大学生の意向をアンケート調査した。種生地区 67 名, 比自岐地区 48 名, 古山地区 61 名。分析単位は(1)全 体，(2)学生の実家の地理的な位置による属性（都市また は農村出身者別)。

\section{III 結果}

\section{1 景観構成要素}

種生地区は山間地域なので，集落を囲む山，棚田の大 きな法面の草, 道が三大構成要素であり, 遠景から中景, 近景になるにつれて法面の草や棚田周囲の木々が細かく 見えてくる。比自岐地区は集居状の集落居住地（家）を 中心に周囲の大面積の水田とさらに平坦部を取り囲む山 が三大構成要素である。遠景, 中景の背景は木（里山） であり，前景及び主景には必ず田が見える。古山地区は 谷筋の傾斜地にある集落なので，木々，道，家又は水田 の四大景観構成要素となっている。遠景では木々, 立地 点の道, 遠望できる家々の混在する景観であり, 水田は 小規模なためその他の景観構成要素に埋没し近景になる まで見えてこない。

\section{2 景観アンケート}

(1)種生地区ーほぼ全員の住民が種生の景観として特徴の あるとしたものは,「里山の木が迫る宅地」,「ホタル水 路 (自然水路)」, 「兼好塚 (吉田兼好の庵の跡)」等設定 し提示した景観シーンの中で多くある。一方，種生の景 観として特徴があるとはされなかったのは,「圃場整備 田」, 「農村公園」, 「避難場所」, 「桜の植林」,「アジサイ」, 「手入れされている森林」, 「道路関係の景観」等である。 年令別には, 60 才以上が他の年代よりも「地区の特徵 を示している」とする景観が多く，現状肯定的な景観認 識である。30〜 50 才台が「ダムの付け替え道路」を挙 げているのが特徵である。男女別の景観認識には大きな 差異はない。職業別では, 農業者は 60 才以上の層より も多くの景観を「地区の特徴を示している」として挙げ ている。三重短大生では, 農村出身者と都市出身者とは 大きく違わないが, 都市出身者だけが「農村公園」,「窮 屈そうな道」「中山間地域整備事業石碑」を挙げた。 (2)比自岐地区－ほぼ全員の住民が特徵のある景観として
挙げたのは,「集落前に広がる田んぼ」「集落のまわり に広がる山地」,「比自岐神社」,「弘法大師の柿の木」等 である。しかし, 集落居住地（家）内の景観について は，ほとんど無関心である。60才以上はほぼ全部の景 観について,「地区の特徴を示している」と回答してい る。30〜 50 才台は「道」と「緑」の景観について,「地 区の特徴を示している」とするものが多かった。男女別 の回答パターンは同じである。職業別には, 農業者と会 社員とは同じような回答であるが, 会社員は農業・農村 整備事業で整備され, 生まれた景観を挙げなかった。主 婦が多い「その他の職業」が山林等の緑の景観を「地区 の特徵を示している景観」として挙げているのが特徵的 である。三重短大生については,「農村景観のイメージ にあっている景観」として農村出身者だけが挙げた景観 は,「公民館（特に変哲のない建物）」，「溜め池」であり， これらの施設の生活的又は生産的な意味を知っているこ とによると思われる。

(3)古山地区ーほぼ全員の住民が挙げた地区の特徴を示す 景観は,「小学校」,「山林に囲まれた集落」,「田守神社」, 「吉田寺」であり，水田等の農地が挙がってこなかった。 10 ～ 20 才台と 60 才以上の層の回答は同じで,「地区の 特徵を示している」景観として全般的に挙げた。しかし， 30 ～ 50 才台層は「宅地・道」の景観については,「地 区の特徵を示す景観」として挙げていない。壮年層にと っては, 狭く坂の集落道路や密集した宅地は交通上の問 題として考えても, 集落の特徵的な景観としては考えら れないということではなかろうか。女性は素直に「狭い 水田」, 傾斜地にある「宅地・道」の景観を集落の特徵 ある景観として挙げている。農業者は「地区の特徵を示 す景観」として挙げた景観は全般的であり, 会社員やそ の他の属性よりも多く, 現状肯定的な景観認識である。 三重短大生については, 農村出身者と都市出身者とでは かなり異なる結果が出た。農村出身者の意向は地元住民 の意向とほぼ同じであり, 都市出身者だけが挙げたのは, 「集落」,「バス停 (地元の手作り)」の景観, 水環境関係 の景観,「山や宅地が境界となっている狭い農地」の景 観である。

(4)地元住民と都市住民（三重短期大学生）との景観認識 の違いについて - 比自岐地区（表 1）の景観シーンを基 に, 地元住民と都市住民の景観認識の違いについて調査 結果の一部を説明する。

ア.〈集落から伸びる農道〉（図 2 )

圃場整備によって集落から直線的に整備された農道は 地元住民には広域交通幹線でもなく, 生産基盤施設のあ りふれた景観の 1 つとして注目されないが, 都市住民に は直線的な農道と両側に広がる國場の景観は一般化され 


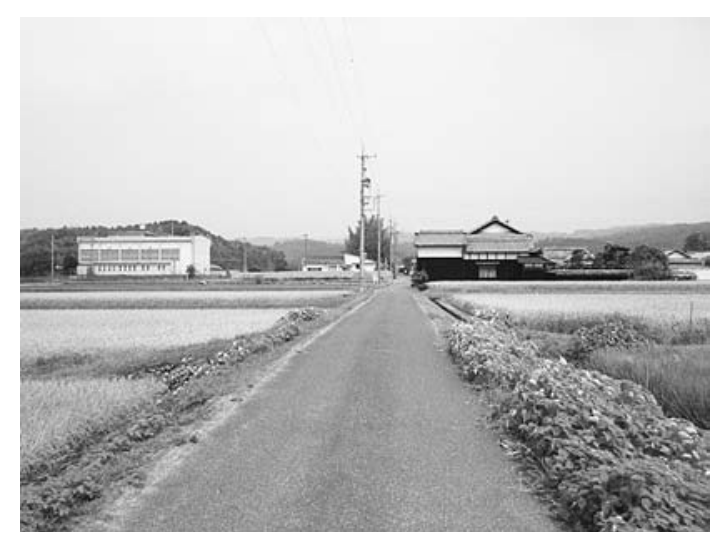

図 2 集落から伸びる農道

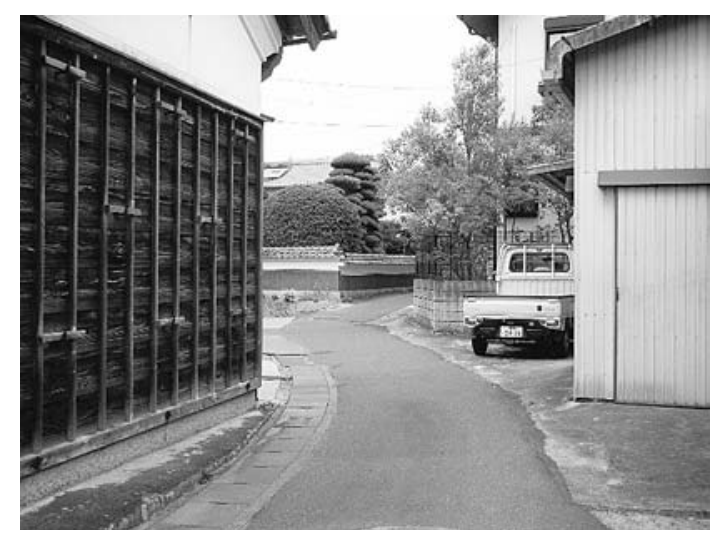

図 3 曲がりくねった集落内道路

た現代的農村イメージであり，景観認識に違いがある。 イ.〈曲がりくねった集落内道路〉（図 3 )

曲がりくねった集落内道路の景観は，地元住民には交 通上不便で危険な道路であり，マイナスイメージが強い 日常空間であり，取り立てて特徵的な農村景観として認 識されないが, 都市住民には集落空間の特徵を示す農村 景観の 1 つとして認識される。

ウ. 溜め池 (図 4 )

比自岐地区に複数ある溜め池は比自岐川上流に滝川ダ ムが完成しているものの, 現在も利用されている。溜め 池の景観は地元住民, とりわけ農業者や高齢者には農業 生産基盤施設としての有用性を認められても, 地区全体 としては取り立てて特徴的な景観としては認識されてい ない。しかし, 実際には転落や洪水の危険があるものの 都市住民には農村らしさを示す水辺空間として認識され る。

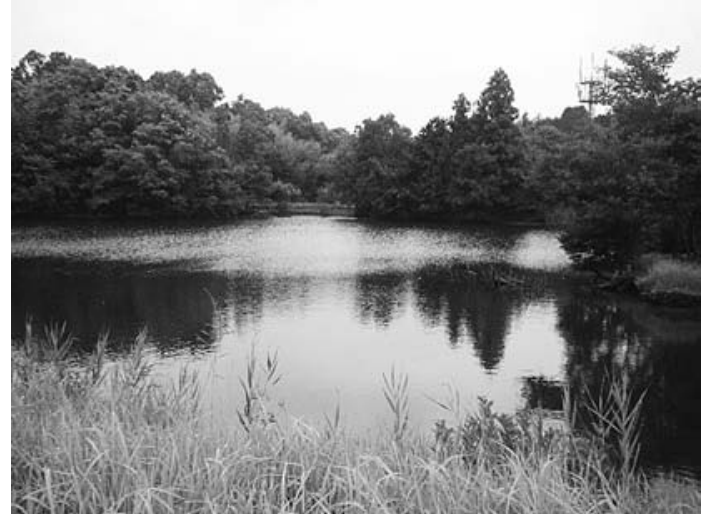

図 4 溜め池

\section{IV まとめ}

農村地域の景観は自然的な景観構成要素の比重が大き く, 土地利用の維持管理が地域景観の質を決定する大き な要因である。集落の地理的条件や支配的な土地利用を 示す農村景観が地元住民から特徵ある景観として，また 三重短大生のうち農村出身者から農村のイメージに合う 景観として認識された。三重短大生のうち都市出身者は 己の農村景観イメージに合う農村景観を制約無く幅広く 挙げていている。前者をいわば「現実的な景観認識」と すると, 後者をいわば「本質的な景観認識」と言えるか もしれない。農村景観を問題にするとき，「本質的な景 観認識」が不適当であるとすることは容易には出来ない であろう。「現実的な景観認識」のみ取り上げるとすれば, 景観形成の目標は低くなり景観保全や環境保全に留まり がちである。「本質的な景観認識」は農村地域の事情に 疎く的確性にかけても新たな農村景観の形成への可能性 を示している。今後, 大変難しいが農村に期待される「本 質的な景観認識」について吟味する研究も必要であり, その上で農村景観の形成は「現実的な景観認識」と「本 質的な景観認識」をあわせて検討することから得られる 新たな方針で臨む必要がある。

\section{参考文献}

1 ）農林水産省（2010）:『農村に扔ける景観配慮の技術マニュ アルーデザインコード活用手法——視点場設定手法—』

As for the landscape of the rural area, a natural landscape componentry holds big specific gravity.Therefore, it is the greatest factor that maintenance of the land use decides the quality of the landscape of the rural area.There are realistic landscape recognition by the rural resident and essential landscape recognition by the city inhabitants in the recognition about the landscape of the rural area.The code for the landscape formation of the rural area must be examined by these both sides.

Key Words:1) Rural Landscape, 2) Landscape Plan, 3) Landscape Recognition 